

\title{
Analysis of Thinking Skills Targeted for Development by Activities in Life Science Textbooks
}

\section{Research Article}

\section{Emel BAYRAK OZMUTLU1, Erhan YAYLAK²}

${ }^{1}$ Ordu University, Faculty of Education, Department of Primary Education, Ordu, Turkey, ORCID: 0000-0002-1222-3557

${ }^{2}$ Ordu University, Faculty of Education, Department of Social Studies Education, Ordu, Turkey, ORCID: 0000-0003-4612-3041

To cite this article: Bayrak-Ozmutlu, E., \& Yaylak, E. (2021). Analysis of thinking skills targeted for development by activities in life science textbooks, International Online Journal of Educational Sciences, 13(2), 390-421.

\begin{tabular}{|c|c|}
\hline ARTICLE INFO & ABSTRACT \\
\hline Received: 06.05.2020 & $\begin{array}{l}\text { In this research, the aim was to complete a broad description related to life science textbooks } \\
\text { activities. Within this description's scope, the aim was to investigate the distributions in terms of } \\
\text { thinking skills targeted for development with activities, the aim, learning experience for the student, } \\
\text { form of work, and sources required for the activity included in life science textbooks. The research }\end{array}$ \\
\hline Available online: & adopted the document analysis method from among qualitative research models. The study group \\
\hline \multirow[t]{12}{*}{ 10.04.2021 } & for the research included 497 activities included in 3 life science books published in the year 2018 and \\
\hline & had open access in the electronic environment through the educational information network (EBA) \\
\hline & platform. The research findings show textbooks targeted the development of 16 different thinking \\
\hline & skills. More than half of the activities focused on the thinking skills of explanation, recall, and \\
\hline & differentiation. Activities to prepare for learning appeared to have the highest rate. The study's form \\
\hline & was analyzed, with the activity rate in the form of group study below $2 \%$. When activities in life \\
\hline & science textbooks are investigated in terms of students' learning experience, $9.5 \%$ of activities are \\
\hline & directed toward thinking about real-life situations. In comparison, $2.6 \%$ are directed toward solving \\
\hline & real-life problems. Finally, nearly all activities included in the textbooks examined could be \\
\hline & completed with prior learning of the student and the textbook's information. The number of life \\
\hline & science textbooks developing higher-order thinking skills, deepening learning, group work for \\
\hline & $\begin{array}{l}\text { students, and directing primary and secondary information sources should be increased. More } \\
\text { weight should be given to activities structured based on real-life situations in textbooks. }\end{array}$ \\
\hline
\end{tabular}

Keywords:

C 2021 IOJES. All rights reserved

Life Science Course, Textbook, Activity, Thinking skills

\footnotetext{
${ }^{2}$ Corresponding author's address: Ordu University, Faculty of Education, Ordu, Turkey.

Telephone: +905437173246

e-mail: erhanyaylak@gmail.com / erhanyaylak@odu.edu.tr

DOI: https://doi.org/10.15345/iojes.2021.02.005
} 


\section{Introduction}

To fulfill our current century's requirements, it is mandatory to move beyond ordinary skills and capabilities (Binkley et al., 2012). In the 21st century, higher-order thinking skills like being able to critically examine information, compare with other sources, and decide about the accuracy of information are accepted as necessary (Orhan, Göksün \& Kurt, 2017). The variation in what is expected from individuals under social conditions is effective in decisions about educational targets. Studies analyzing the world of the future from various angles emphasize the necessity to give weight to teaching higher-order thinking skills making it possible to use it within original concepts, rather than educational organizations directly transferring information (Harari, 2018). An extension of the developments mentioned in brief above can be seen in developing skills-focused curricula in Turkey and the world. For example, in America alone, more than 100 programs have been developed about thinking skills after 1980 (Jonhson \& Siegel, 2010). In Turkey, when the curriculum's aim and vision updated in 2018 are examined, higher-order thinking skills are underlined [Ministry of National Education (MoNE), 2018].

To cultivate individuals to respond to the age requirements, great importance needs to be given to higher-order thinking and in-depth learning skills during educational systems design (Kutlu, Doğan \& Karakaya, 2010; Senemoğlu, 2011). One of the essential topics requiring attention to reach this aim in studies completed in schools is content. Suppose it is necessary to state it more clearly. In that case, the form of use of the content may be explained as analysis of content to be taught within the scope of a lesson (discipline) in terms of the potential to develop thinking skills and the design of activities to occupy students in the teachinglearning process in line with this. For the development of thinking skills, it is necessary for students to interact with the correct content ineffective form, because skills cannot be developed without gaining knowledge and knowledge that does not transform into skills is insufficient for daily activities within a changing world (Baysal, Çarıkçı \& Yaşar, 2016). Resnick (2010), similarly, stated that thinking skills rarely develop independently of any content. From this aspect, analysis of lesson (discipline) content in terms of development potential for thinking skills and using this analysis data during curricula and textbooks carry great importance.

Another essential topic among studies completed about thinking skills is classification models developed about skills. With the different appearance in terms of preliminary requirements and complexity, it is necessary to classify teaching decisions about thinking skills based on a range of criteria. Models based on classification of thinking skills provide guiding information for making many teaching decisions led by the development of curricula and measurement tools (Anderson \& Krathwohl, 2001; Bloom, 1956; Gagné \& Briggs, 1979; Haladyna, 1997; Marzano, 2001; Romizowski, 1981; Beyer, 1984). Studies about this topic appear to have classified thinking skills in the broadest context as basic and higher-order skills (Beyer, 1984). Basic thinking skills are expressed as singular skills, while skills requiring using several basic skills are defined as higherorder thinking skills. When the Bloom taxonomy (Anderson \& Krathwohl, 2001) is reviewed, with similar classification, lower-level thinking skills are recall, understanding, and application, while higher-order thinking skills are analysis, evaluation, and creation.

In the relevant literature, debates about the teaching of thinking skills within the scope of 21st-century skills appear to have intensified in studies (Zayimoğlu-Öztürk, 2020). Thinking skills teaching has gained a new dimension with 21st-century skills. In short, 21st-century skills involve a broad approach comprising skills, attitudes, and information required for students' success in school, work, and public life. Simultaneously, the focus has been on what students can do with data and how to apply it within authentic contexts (Larson \& Miller, 2012). What 21st-century skills encompass has formed policy-makers and researchers' plan for a duration longer than ten years. In this process, a variety of educational interventions were made, including in the USA, Australia, Japan, England, and Northern Ireland, and a range of skill sets as defined by the European Union and the Organization for Economic Cooperation and Development (OECD) 
(Binkley et al. 2012). Different classifications have been made by various organizations about what 21stcentury skills involve; they each have a common point of emphasizing higher-order thinking skills.

Within the scope of 21st-century skills in Turkey, the most concrete step taken in recent years is the Turkish Qualifications Framework. The Qualifications Framework (TYÇ, 2015) classified all qualifications gained from the education system and other learning environments from 1st level to 8th level. Each level is defined in terms of 'knowledge, skills, and competencies. The components of this 8-level structure are primary qualifications, unit qualifications, special target qualifications, and supportive qualifications. The life-long learning skills that each individual is expected to attain are defined as critical competencies. These key competencies are communication in the mother language, communication in foreign languages, mathematical competency and essential competencies in science/technology, digital competency, learning to learn, competencies related to social and citizenship, taking the initiative and innovation, cultural awareness, and expression. To gain these qualifications, the responsibility lies with the Ministry of National Education (MEB), the Council of Higher Education (YÖK), and organizations and institutions within the scope of law number 5544 (Gelen, 2017). The curriculum updated in 2018 dealt with the Turkish Qualifications Framework under the heading of competencies to be developed within its scope. Additionally, the revised curriculum includes 23 skills specific to the life science lesson (MEB, 2018). All these interventions can be interpreted as adopting an approach to developing thinking skills in the curriculum in common with developments in the rest of the world.

Table 1. Skills in Life Science Curriculum

\begin{tabular}{ll}
\hline 1. Research & 13. Self-protection \\
2. Use information and communication technologies & 14. Know yourself \\
3. Perceiving change and continuity & 15. Personal care \\
4. Balanced nutrition & 16. Compliance with the rules \\
5. Nature maintenance & 17. Space perception \\
6. Entrepreneurship & 18. Recognizing national and cultural values \\
7. Observation & 19. Self-management \\
8. Communication & 20. Health protection \\
9. Cooperation & 21. Problem solving \\
10. Decision making & 22. Social participation \\
11. Career awareness development & 23. Time management \\
12. Resource use & \\
\hline
\end{tabular}

The life science lesson has high potential in preparing students for the future world and developing higher-order thinking skills. Life science is centered on experiences about how a child makes sense of the world from birth to about 6-7 years of age and is a lesson targeting gaining knowledge, skills, and values related to later life, attempting to assist in understanding surroundings in social and physical terms (Kabapınar, 2014) and preparing children for life and higher educational stages by gaining life skills (Karabağ, 2009). This lesson leads the lessons that ensure children's development from many angles and help develop thinking skills (Akınoğlu, 2003). However, for life science lessons to be used at maximum potential about developing thinking skills, it is mandatory that all elements within the teaching-learning process have the correct qualities. Textbooks are the leading example of these elements. Textbooks are the most fundamental teaching tool ensuring students are occupied with content aiming to develop thinking skills. When a teacher is guided by a textbook constructed with the correct understanding, there is a very high potential for developing higher-order thinking skills. As a result, the level and type of activities included in textbooks should consist of visuals and activities preparing the environment for developing higher-order thinking skills among students and constructing personal meaning (Kabapınar, 2007). 
Although developments in teaching technologies, textbooks' importance continues in-class - teachers complete many activities with textbooks (Ertürk \& Güler, 2017). Due to reasons such as the preparation of curricula by the need for textbooks in the teaching-learning process, there being practical, easy to access and economical, ensuring systematic and accurate use of time and energy of the teacher and allowing the possibility of individual work for students, textbooks have preserved the feature of being the most used tool by teachers (Demirkaya, 2017; EARGED, 2008; Avc1 \& Faiz, 2018). This situation makes the quality of textbooks one of the most significant markers of the teaching-learning process.

The research aims to determine a broad description of activities included in primary school life science textbooks. The activities in the textbooks included in the study were investigated in terms of thinking skills targeted for development, aim, learning experience for students, work, and sources required during the activity. Each dimension investigated provides essential feedback about the quality of experiences that occupy students. Each activity included in life science textbooks was investigated in terms of five dimensions in the research. The first dimension analyzed which thinking skill of students was targeted for development by the activity. In this way, it may be possible to reveal how textbooks serve to develop higher-order thinking skills mentioned in the curriculum. The second dimension investigated in the research is the aim of the activity. This investigation makes it possible to perform an assessment based on empirical data related to deepened learning through repetition or application during the activity. Another dimension of activities investigated is the learning experience of the students. This investigation makes it possible to assess the compatibility between the life science lesson's unique aims and the current teaching-learning concepts of activities in textbooks. The fourth dimension investigated in activities in the research is the form of work in the activities. This investigation ensures the possibility to examine activities in terms of individual or group-based working opportunities. The final dimension investigated for activities included in textbooks requires information sources for the activity. Due to this investigation, it is possible to make inferences about how the textbook directs students toward research and analysis.

Investigation of the relevant literature shows there are studies completed about life science textbooks. Some of these studies investigate research about textbooks (Ütkür, 2018; Güven \& Püsküllü, 2017). Additionally, it is possible to find research investigating (Candan \& Ergen, 2014; Erol \& Kıroğlu, 2014; Öztürk \& Özkan, 2018; Sarıtaş \& Şahin, 2018) and assessing (Gözütok, Taş, Rüzgâr, Akçatepe \& Yetkiner, 2015; Gülüm \& Çeltik, 2014) textbooks in terms of a range of criteria. There was no research encountered investigating activities included in textbooks in terms of the subdimensions in this research. From this aspect, this research will fill an essential gap in the relevant literature in terms of both investigation criteria for textbooks and findings of these criteria. The research findings will make it possible to assess how accurate and effective tool textbooks are for achieving the life science lessons' aims. This research aims to determine a broad description of the quality of activities included in life science textbooks. Within this scope, the answers to the following research problems were researched:

1. What type of distribution do activities included in life science textbooks have in terms of thinking skills targeted for development, aims, students' experiences, students' work, and sources required by students?

2. What type of distribution do activities included in life science textbooks have in terms of thinking skills targeted for development, in terms of aims, in terms of experiences of students, in terms of the form of work of students, and duration of sources required by students according to the class level variable?

\section{Method}

This section aims to reach impartial interpretations of the findings by explaining the research design, data collection, and analysis in detail. 


\section{Research Design}

This research aimed to investigate the distribution of activities included in textbooks updated with the primary school life science curriculum updated in 2018 in terms of thinking skill targeted for development, aim, learning experience for students, work, and sources required during the activity. In line with the research aims, it was necessary to investigate the study group's textbooks' activities. As a result, the research adopted the document analysis method, one of the qualitative research methods. According to Scott and Marshall (2015), documentary research is "research that uses personal and official documents as source material. Documents... may include such things as newspapers, diaries, stamps, directories, handbills, maps, government statistical publications, photographs, paintings, gramophone records, tapes, and computer files." In this research, a total of 3 books from the social studies field, which began to be used in 2018 and were accessed through the EBA digital platform, were investigated and analyzed. From this aspect, it was considered appropriate to use the document research method in the research.

\section{Research Documents}

The targeted sample type of criterion sampling was used in this research. Criterion sampling is defined as selecting all situations abiding by specific criteria (Patton, 2014). The research sample selection determined the measures as textbooks implemented in primary school life science lessons during the 2018-2019 academic year and textbooks accessible digitally through the EBA platform. The study group in the research comprised three life science textbooks that entered use in 2018 and were electronically accessible through the EBA platform. Information about books forming the study group in the study is shown in Table 2.

Table 2. Books and Publishers Investigated within the Scope of the Research

\begin{tabular}{lclc}
\hline Lesson & Grade & Publisher & Total \\
\hline \multirow{3}{*}{ Life Sciences } & 1st & Ardıç Publishing & 1 \\
& 2nd & Ministry of National Education Publishing & 1 \\
& 3rd & Evren Publishing & 1 \\
\hline
\end{tabular}

\section{Data Analysis Process}

For data analysis in the research, an intense analysis process was followed, comprising three repeated reading, coding, and continuous comparison methods. All analyses in the study were performed with the MaxQDA 2020 program. In the first stage of analysis, three textbooks included in the study group were loaded into the program. The activities to be analyzed in the scope of the research were determined by two researchers together. All work in the study textbooks, including questions to students, homework, and directions like discuss, research, investigate and record, were assessed as activities. Table 3 gives the distribution of activities included in the analysis according to the textbook.

Table 3. Distribution of Activities in Books Investigated in the scope of the research

\begin{tabular}{lcc}
\hline Lesson & Grade & Number of Activities \\
\hline \multirow{3}{*}{ Life Sciences } & 1st & 138 \\
& 2nd & 186 \\
& 3rd & 173 \\
\hline
\end{tabular}

The document analysis stage was completed separately by two researchers. The activities in the research were coded according to the hypothesis coding method. Codes are developed based on theories/predictions about what will be found in data before gathering or analyzing data (Saldana, 2019). In the coding activities stage, each activity was repeatedly read, and notes about what was requested of students within the activity scope were recorded in the analysis menu's notes section. During analysis, each activity was coded in the five 
separate dimensions equivalent to the research subproblems.

In the process of coding each dimension, different questions were directed toward the activity. These questions were as follows;

1. What thinking skills will be developed by the student who completes the requirements of the activity?

2. What is the aim of the activity?

3. What learning experience does the activity direct students towards?

4. What is the form of work in the activity?

5. What are the information sources required by students to perform the activity?

In the analysis process, the explanations of why the activity was coded with this name were found in the explanation section for each code created by the two researchers. These explanations were investigated for the assessment of compliance between coders. The coding outcomes and explanations required for codes were applied to all 497 activities. After completing the analysis process, the two researchers met, and intercoder compatibility coefficients were calculated. After calculations, the intercoder compatibility coefficient was determined as $96 \%$. All activities coded differently by the researchers were investigated. During this process, the researchers' notes and explanations related to the codes during the analysis process were explored. This process was repeated for each activity coded differently by the two researchers. Common assessments continued until no incompatible principles remained. After completing the coding process, activities were classified based on the distribution according to the five dimension classes. According to variables researched in response to the thinking skills research problem, the distribution was summarized using descriptive statistics. After this analysis, the research problems were answered. The life science textbooks investigated within this research framework were coded as LSTB1, LSTB2, and LSTB3.

\section{Validity and Reliability Studies}

In this research adopting the qualitative research method, the following studies were performed within the validity and reliability studies. One of the validity and reliability studies in qualitative analysis of plausibility means the accuracy and persuasiveness of the gathered data (Güler, Halıcıoğlu \& Taşgın, 2014). The data in this research was investigated in textbooks used in state schools in Turkey in 2018-2019 and digitally accessed through the EBA platform. Data analyzed in the scope of the research were taken from the printed forms of the textbooks. From this aspect, it can be said that the data investigated in the study abided by the plausibility requirement. Another way to ensure plausibility in qualitative research is to explain the number and features of the study group, how they were chosen, the data collection tools used in the study, and the analysis techniques (Creswell \& Miller, 2000). Within the scope of this necessity, the information mentioned above is explained in detail under the method heading. Within the range of this requirement, the analysis was completed independently by two researchers. When each of the two researchers decided what thinking skill was targeted for development by data analysis activities, they used explanations developed based on the investigation of the relevant literature. One of the researchers was a lecturer in social science education, while the other was a lecturer in curriculum and teaching. The reliability formula 'reliability = consensus / (consensus + difference) x 100' recommended by Miles and Huberman (2016) was used to calculate the research's reliability. The results of the calculation determined the reliability of the study was $96 \%$. During data analysis, each researcher provided notes related to coding about why the outcome was that thinking skill. For analysis of results that were not compatible between coders, these notes and explanations developed based on the relevant literature investigation were assessed together. Assessment continued until an agreement was reached about each coded outcome. Validity in qualitative research can be ensured by diversifying data, 
detailed explanations about the study group's features, reporting data in detail, and citing directly from the data (Creswell, 2014; Johnson \& Christiensen, 2014). As a result, the class level and page numbers for textbooks are given in codes, and the frequency and percentages of codes included in textbooks are presented as figures. Additionally, codes given in the presentation of findings are stated openly and clearly and supported with direct citations to increase the study's validity and reliability.

\section{Findings}

The data obtained from life science textbooks investigated in the research were divided into five categories. These are thinking skills targeted for development by activities included in textbooks, aims of the activities, learning experiences activities direct students towards, work during activities, and students' sources during activities.

\section{Thinking skills targeted for development by activities included in life science textbooks.}

In the context of the first subproblem in the research, attempts were made to determine the thinking skills targeted for development by activities included in life science textbooks. These thinking skills are given in Figure 1.

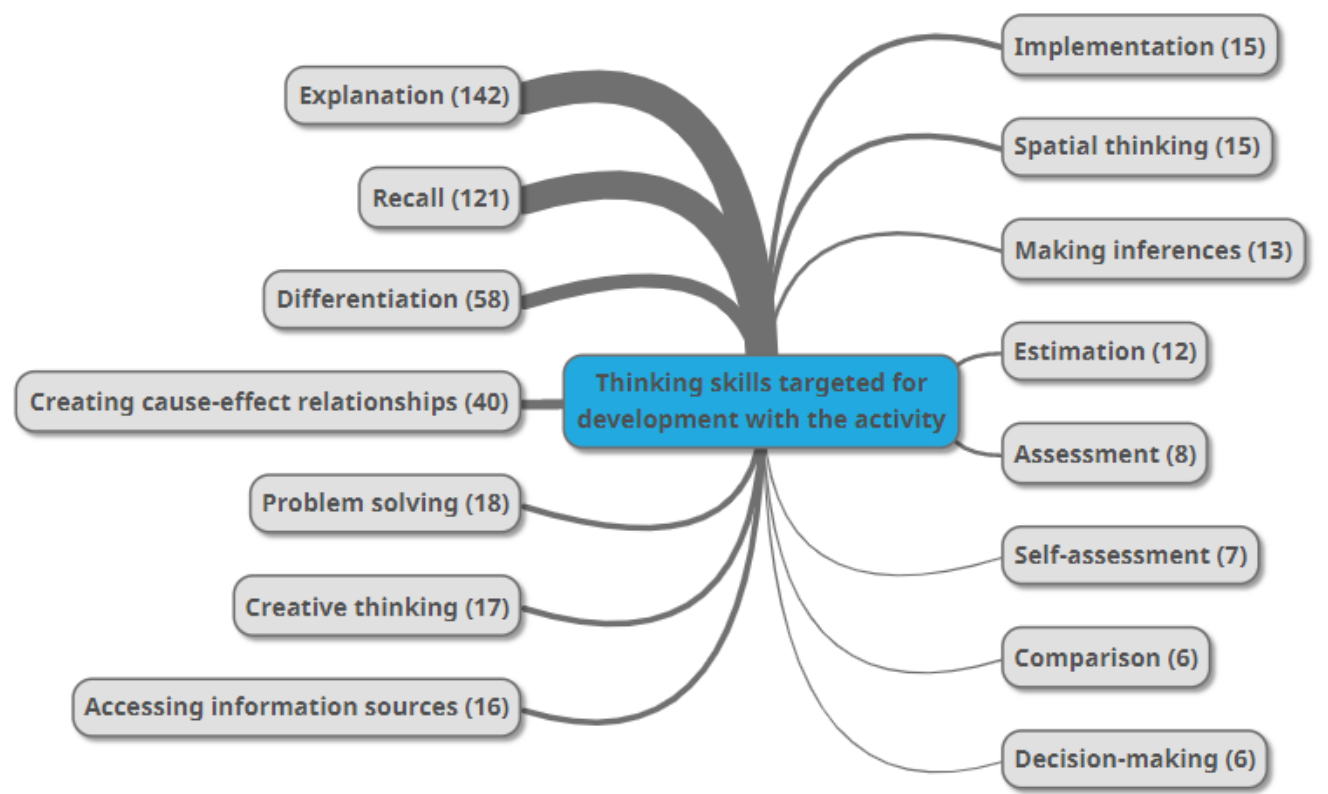

Figure 1. Thinking skills targeted for development with activities included in life science textbooks.

When Figure 1 is investigated, the codes for the thinking skills targeted for development with the activity category were determined. These were explanation (f:142; 28.8\%), recall (f:121; $24.3 \%$ ), differentiation (f:58; 11.7\%), creating cause-effect relationships (f:40; 8.0\%), problem solving (f:18; $3.6 \%$ ), creative thinking (f:17; 3.4\%), accessing information sources (f:16; 3.2\%), implementation (f:15; 3.0\%), spatial thinking (f:15; 3.0\%), making inferences (f:13; $2.6 \%$ ), estimation (f:12; $2.4 \%)$, assessment (f:8; $1.6 \%)$, self-assessment (f:7; $1.4 \%)$, comparison (f:6; $1.2 \%$ ), decision-making (f:6; $1.2 \%$ ) and conversion (f:3; $0.6 \%$ ) for a total of 497 codes.

In the explanation code, included in the category of thinking skills targeted for development during activities included in life science textbooks, examples include 'how did you feel on the day you started school?" (LSTB1, p.13). An example of the recall code is 'Give examples of statements of kindness. Say what situations you would use these statements in.' (LSTB2, p.36). An example of the differentiation code is 'In which of the following pictures are the children abiding by the game rules? Color that picture.' (LSTB2, p.44). For the creating cause-effect relationships code, an example is 'Why is neighborliness important? Explain with an example.' (LSTB3, p.60). An example of the developing solution recommendations code is 'What can you do to make life easier for those migrating from different countries to our country?' (LSTB2, p.174). For the creative 
thinking code, an example is 'Using the picture at the side write a poem or short story explaining the importance of living together.' (LSTB1, p.154). An example of the accessing information sources code is 'Let's research historical and touristic sites in the place where you live. Stick photographs related to these places below. Write the information requested underneath.' (LSTB1, p.150). For the implementation code, an example is 'Write memos stating your needs and wants for your class and your school. Put these memos into the wish box.' (LSTB3, p.37). An example of the spatial thinking code is 'Paint our country's capital city and the place where you live on the map below.' (LSTB2, p.154). An example of the making inferences code is 'If we didn't have technological products, what problems would we face at home? Explain.' (LSTB3, p.68). For the estimation code, an example is 'What could happen after Yasemin comes to school?' (LSTB1, p.13). An example of the assessment code is 'Examine the picture at the side. Say which traffic rules are being broken." (LSTB3, p.116). For the self-assessment code, an example is "The following form was organized for you to assess yourself. Mark the appropriate choice for you with ' $\checkmark$. " (LSTB2, p.20). An example of the comparison code is 'State similarities and differences between you and your desk mate." (LSTB1, p.16). For the decision-making code 'Examine the following picture. If there was such a fire in your home, what would you do? Explain' (LSTB3, p.129). An example of the conversion code is 'Explain your feelings and thoughts about school with a picture.' (LSTB1, p.48). According to class level, the distribution of thinking skills targeted for development during life science textbooks is given in Figure 2.

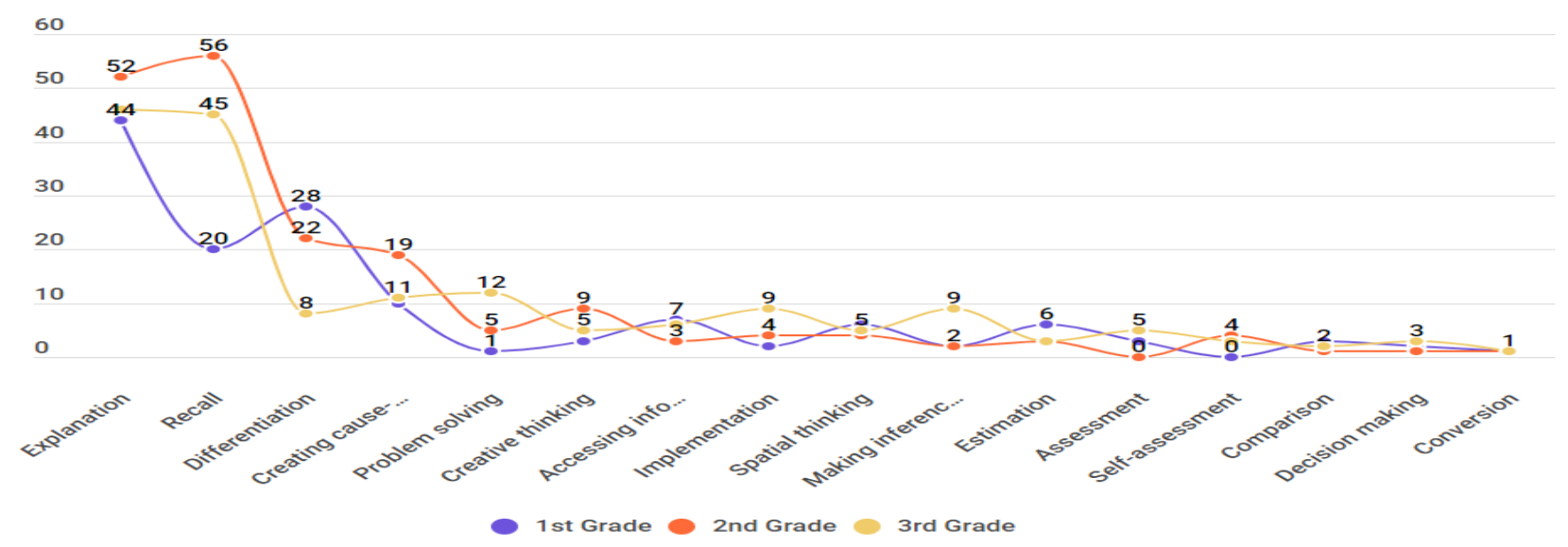

Figure 2. Distribution of thinking skills targeted for development with activities included in life science textbooks according to class level.

When Figure 2 is investigated, the distribution of thinking skills targeted for development during activities included in life science textbooks is seen. Accordingly at 1st class level, thinking skills were explanation (f:44; 31.9\%), recall (f:20; $14.5 \%$ ), differentiation (f:28; 20.3\%), forming cause-effect relationships (f:10; $7.2 \%)$, problem solving (f:1; $0.7 \%)$, creative thinking (f:3; $2.2 \%)$, accessing information sources (f:7; $5.1 \%)$, implementation (f:2; $1.4 \%$ ), spatial thinking (f:6; $4.3 \%$ ), making inferences (f:2; $1.4 \%$ ), estimation (f:6; $4.3 \%$ ), assessment (f:3; $2.2 \%$ ), self-assessment (f:0; $0 \%$ ), comparison (f:3; $2.2 \%$ ), decision making (f:2; $1.4 \%$ ), and conversion (f:1;0.7\%). At 2nd class level, thinking skills and rates were explanation (f:52; 28.0\%), recall (f:56; $30.1 \%$ ), differentiation (f:22; $11.6 \%$ ), forming cause-effect relationships (f:19; 11.8\%), problem solving (f:5; $2.7 \%$ ), creative thinking (f:9; $4.8 \%$ ), accessing information sources (f:3; $1.6 \%$ ), implementation (f:4; $2.2 \%)$, spatial thinking (f:4; $2.2 \%$ ), making inferences (f:2; 1.1\%), estimation (f:3; $1.6 \%$ ), assessment (f:0; $0 \%$ ), self-assessment (f:4; 2. \%2), comparison (f:1;0.5\%), decision making (f:1;0.5\%), and conversion (f: $1 ; 0.5 \%)$. At 3rd class level, thinking skill and rates were explanation (f:46; $26.6 \%$ ), recall (f:45; $26.0 \%)$, differentiation (f:8; $4.6 \%$ ), forming cause-effect relationships (f:11; 6.6\%), problem solving (f:12;6.9\%), creative thinking (f:5; $2.9 \%$ ), accessing information sources (f:6; 3.5\%), implementation (f:9; 5.2\%), spatial thinking (f:5; 2.9\%), making inferences (f:9; $5.2 \%)$, estimation (f:3; $1.7 \%)$, assessment (f:5; $2.9 \%$ ), self-assessment (f:3; $1.7 \%)$, comparison (f:2; $1.2 \%)$, decision making (f:3; $1.7 \%$ ), and conversion (f:1; $0.6 \%$ ). Based on the data in Figures 1 and 2, it appears the life science 
textbooks have similar trends in 1st to 3rd class. This trend is observed as the textbooks mostly include simple thinking skills like explanation and recall, while thinking skills that are complicated, difficult and deepen learning like comparison, decision-making and conversion are included less often.

\section{Aims of activities included in life science textbooks}

In the context of the second subproblem in the research, attempts were made to determine the aims of the activities included in life science textbooks. The determined aims are given in Figure 3.



Figure 3. Aims of activities included in life science textbooks.

When Figure 3 is investigated, it was concluded that activities in life science textbooks were prepared in the context of four aims. These aims are repeating what was learnt (f:241; 48.5\%), preparing for learning (f:139; 28.0\%), deepening learning (f:88; 17.7\%) and applying what was learnt (f:29; 5.8\%). Examples of repeating learning in the category of aims of activities included in life science textbooks are 'Let's examine the picture below. Let's determine and mark the pictures with students making mistakes.' (LSTB1, p.20), 'Mark the behavior below that you can do. Color the pictures you marked.' (LSTB2, p.15) and 'What can be done to use resources more efficiently? Explain' (LSTB3, p.89). For the preparing to learn code, examples include 'Is it fair that only one member of the family does housework? Why?' (LSTB1, p.63), 'What information is included in your home address?' (LSTB2, p.60) and 'What should you pay attention to when spending money?' (LSTB3, p.46). Examples of the deepening learning code are 'Why is it important to learn your friend's name?' (LSTB1, p.15), 'What can you do to contribute to your family's budget?' (LSTB3, p.47) and 'If we did not have the rights and freedoms given to us by the republic, what problems would we meet in our lives? Give examples.' (LSTB3, p.154). For the applying learning code, examples are 'Can you describe your house to a friend?' (LSTB1, p.65), 'Consider the school in the picture below is your school. Complete the picture by drawing the buildings, avenues and streets found around your school.' (LSTB2, p.28), and 'Write memos stating your needs and wants for your class and your school. Put these memos into the wish box.' (LSTB3, p.37). According to class level, the distribution of aims of activities included in life science textbooks is given in Figure 4.



Figure 4. Distribution of aims of activities included in life science textbooks according to class level. 
Figure 4 shows the distribution of aims of activities included in life science textbooks according to class level. Accordingly, at 1st class level, aims and rates were preparing to learn ( $\mathrm{f}: 68 ; 49.3 \%$ ), repeating learning (f:48; 34.8\%), deepening learning (f:17; 12.3\%), and applying learning (f:5; 3.6\%). At 2nd class level, aims of activities and rates were preparing to learn (f:50; 26.8\%), repeating learning (f:93; 50.0\%), deepening learning (f:34; 18.3\%), and applying learning (f:9; $4.8 \%$ ). At 3rd class level, activity aims, and rates were preparing to learn (f:21; 12.1\%), repeating learning (f:100; 58.0\%), deepening learning (f:37; 21.9\%), applying learning (f:15; $8.7 \%)$. When Figures 3 and 4 are investigated, life science textbooks' activities provided repeated learning rather than an application or putting information learned into practice.

\section{The learning experience for students of activities included in life science textbooks}

In the context of the third subproblem in the research, attempts were made to determine which learning experiences students were directed towards during activities included in life science textbooks. These learning experiences are given in Figure 5.

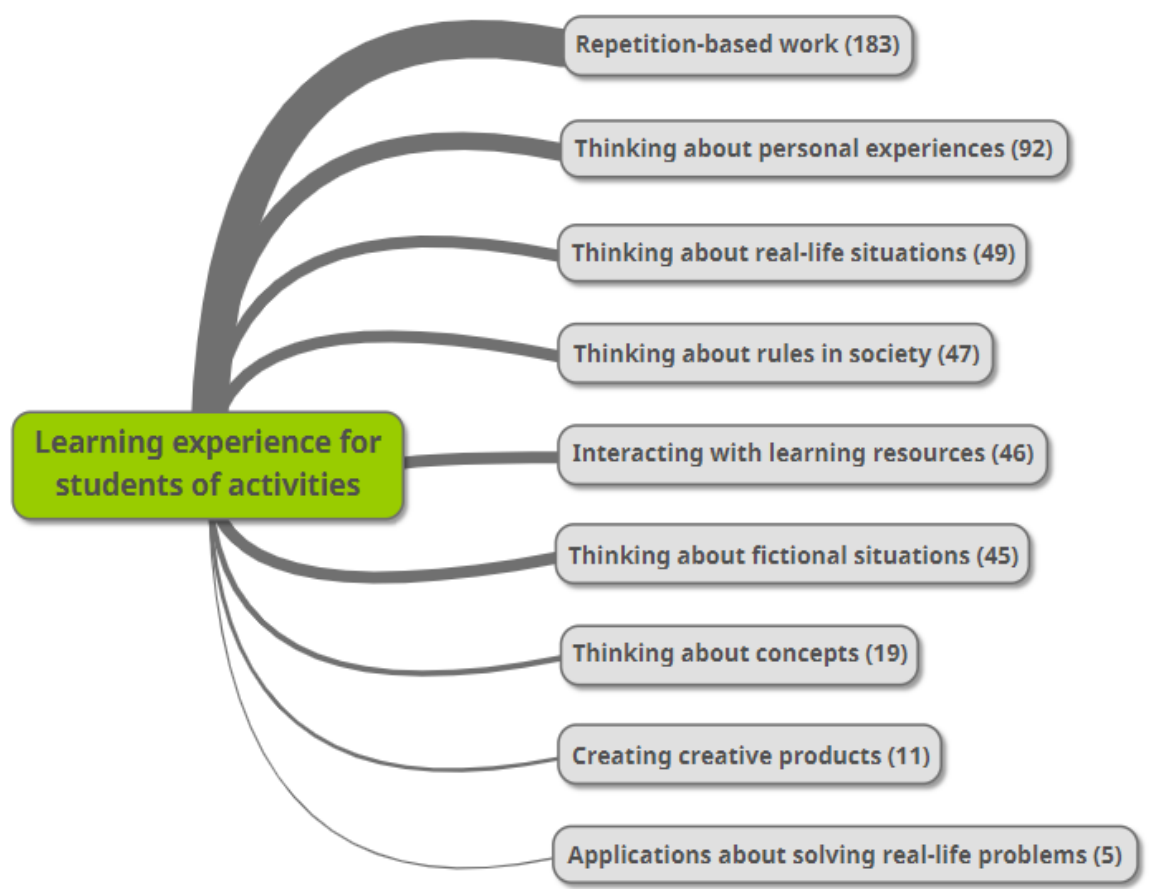

Figure 5. The learning experience for students of activities included in life science textbooks.

When Figure 5 is investigated, the learning experiences students were directed towards during activities included in life science textbooks were determined as repetition-based work (f:183; 36.8\%), thinking about personal experiences (f:92; 18.5\%), thinking about real-life situations (f:49; 9.6\%), thinking about rules in society (f:47; 9.5\%), interacting with learning resources (f:46; 9.3\%), thinking about fictional situations (f:45; 9.1\%), thinking about concepts (f:19; 3.8\%); creating creative products (f:11; \%2.2) and applications about solving real-life problems (f:5; $1.0 \%)$.

In the learning experiences directed by activities included in the life science textbook category, an example of the repetition-based work is 'Aslı and Cemil describe their places in their classes. Look at the picture. Can you show Asli and Cemil's places in their classes?' (LSTB1, p.21). For thinking about personal experiences, an example is 'What should you pay attention to when spending money?' (LSTB2, p.46). An example of thinking about real-life situations is 'How would you use nature to find your orientation? Explain.' (LSTB3, p.202). For thinking about rules in society, an example is 'Some of the rules you must abide by in your class are given below. Write why you must abide by these rules.' (LSTB2, p.24).

An example of the interacting with learning resources code is 'Let's learn the name of the place we live, its clear characteristics and products from older members of your family.' (LSTB1, p.144). For thinking about 
fictional situations, an example is 'What could happen after Yasemin comes to school?' (LSTB1, p.13). An example of thinking about concepts is 'What does the word saving make you remember?' (LSTB2 p.81). For the creating innovative products code, 'Determine slogans related to efficient use of resources' (LSTB3, p.42) and for applications about solving real-life problems 'Bring books you have read to class to donate. With your teacher's help, give these books as a gift to schools that need them.' (LSTB3, p.33). The distribution of experiences students are directed towards by activities included in life science textbooks is given in Figure 6.

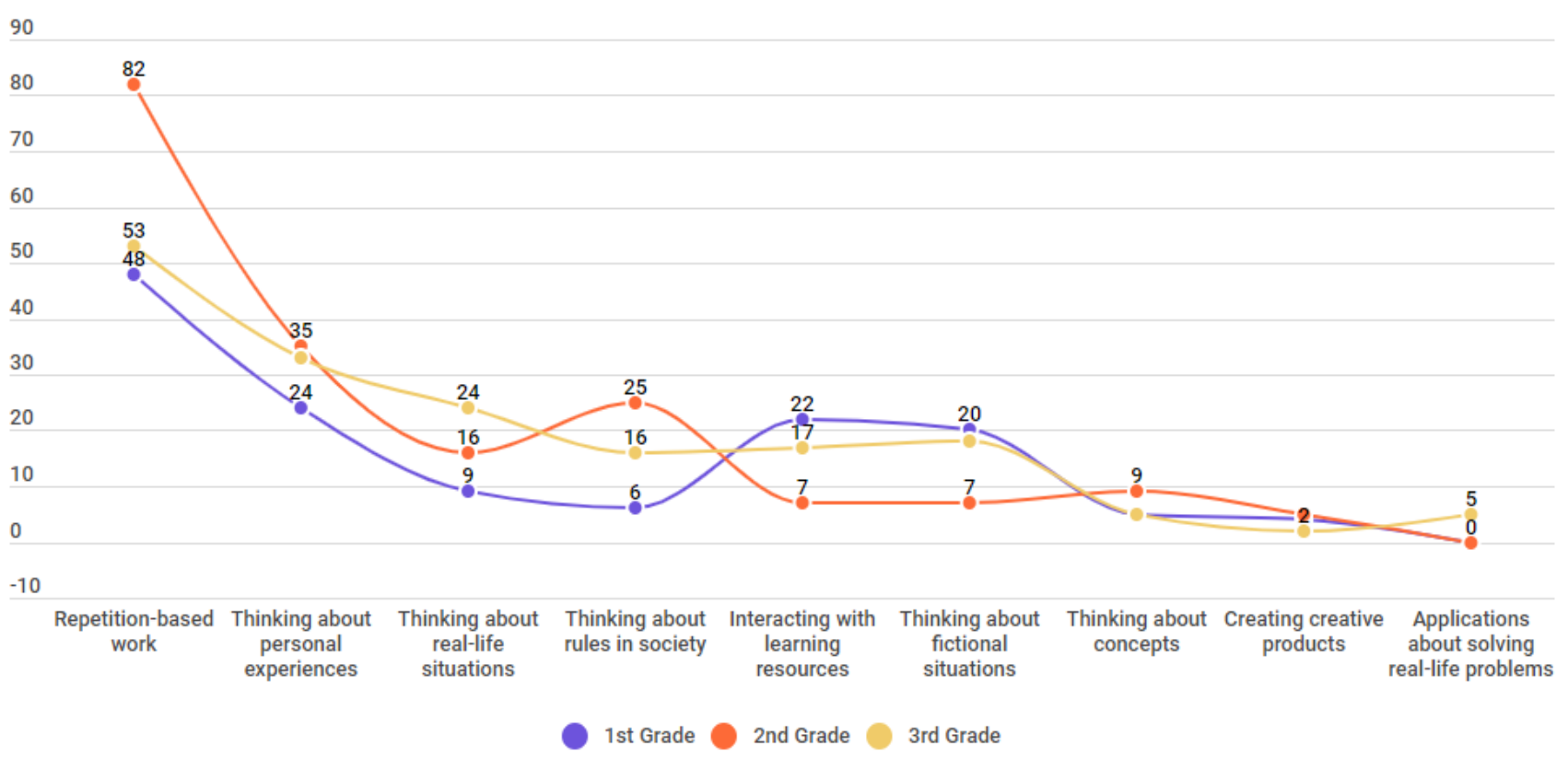

Figure 6. Distribution of learning experiences for students of activities included in life science textbooks according to class level.

When Figure 6 is investigated, the distribution of learning experiences students are directed towards by activities included in life science textbooks can be seen. Accordingly, at 1st class level, activities in life science textbooks directed students towards repetition-based work (f:48;34.8\%), thinking about personal experiences (f:24; $17.4 \%)$, thinking about rules in society (f:6; 4.3\%), thinking about real-life situations (f:9; 6.5\%), thinking about fictional situations (f:20; 13.7\%), interacting with learning resources (f:22; 14.5\%), thinking about concepts (f:5; 3.6\%), designing creative products (f:4; $2.9 \%$ ), and solving real-life problems (f:0; 0\%). At 2nd class level, activities in life science textbooks directed students towards repetition-based work (f:82; 44.1\%), thinking about personal experiences (f:35; $18.8 \%$ ), thinking about rules in society (f:25; $13.4 \%$ ), thinking about real-life situations (f:16; 8.6\%), thinking about fictional situations (f:7; 3.8\%), interacting with learning resources (f:7; 3.8\%), thinking about concepts (f:9; 4.8\%), designing creative products (f:5; $2.7 \%$ ), and solving real-life problems (f:0; $0 \%$ ). At 3rd class levels, activities in life science textbooks directed students towards repetition-based work (f:53; 30.6\%), thinking about personal experiences (f:33; 19.1\%), thinking about rules in society (f:16; 9.2\%), thinking about real-life situations (f:24; 13.9\%), thinking about fictional situations (f:18; $10.4 \%$ ), interacting with learning resources (f:17; $9.8 \%$ ), thinking about concepts (f:5; $2.9 \%)$, designing creative products (f:2; $1.2 \%$ ), and solving real-life problems (f:5; $2.9 \%$ ). Based on data in Figures 5 and 6 , life science textbooks directed students towards learning experiences based on repetitive work and personal experience distant from complexity, deepening learning and application.

\section{Form of work for students in activities included in life science textbooks}

In the context of the fourth subproblem in the research, attempts were made to determine the form of work for students during activities included in life science textbooks. These forms of work are given in Figure 7. 


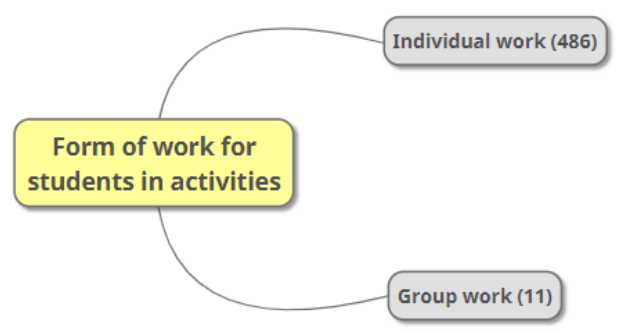

Figure 7. Form of work for students during activities included in life science textbooks.

When Figure 7 is investigated, students' work activities during life science textbooks were coded as individual work (f:486;97.8\%) and group work (f:11;2.2\%). For the form of work category for students during activities included in life science textbooks, examples of the unique work code include 'How did you feel on the day you started school?' (LSTB1, p.13), 'How do you behave towards people you meet when going to school and coming home from school?' (LSTB1, p.19), 'Why is it important for you to know the buildings in the area close to your school?' (LSTB2, p.27), 'Which items in the following pictures do you use for personal care? Mark them' (LSTB2, p.93), 'Create slogans related to efficient use of resources.' (LSTB3, p.42), and 'Which resources do you use during your care? Write them down.' (LSTB3, p.89). According to class level, the work distribution involved in activities science textbooks is given in Figure 8.

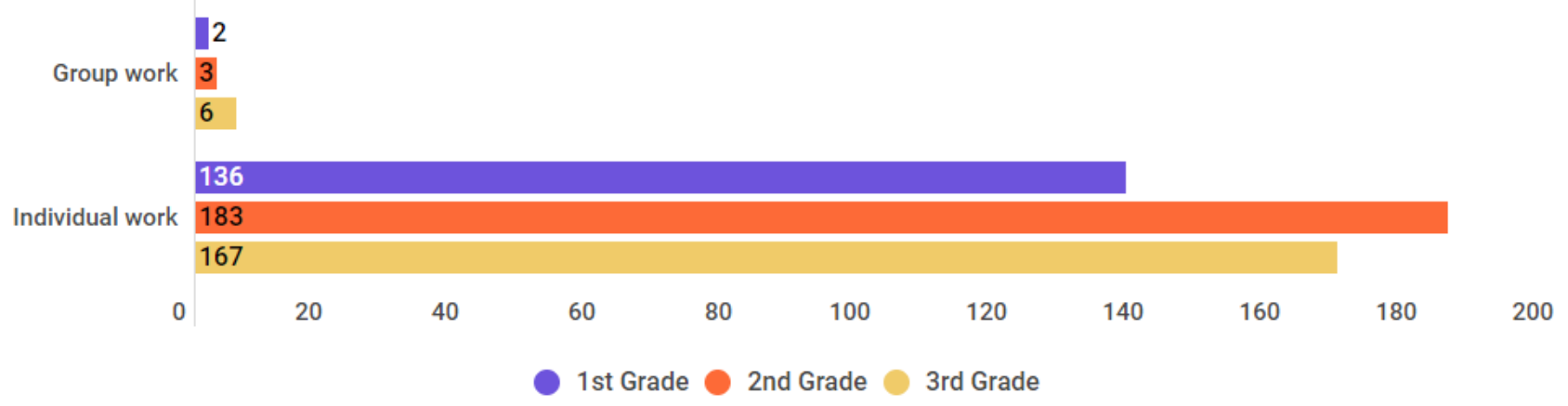

Figure 8. Distribution of form of work for students in activities included in life science textbooks according to level.

When Figure 8 is investigated, the form of work during activities included in life science textbooks according to class level can be seen. Accordingly, the form of work for 1st class life science textbooks is individual (f:136; 98.6\%) and group work (f:2; 1.4\%); in 2nd class life science textbooks it is individual (f:183; 98.4\%) and group work (f:3; $1.6 \%$ ); and in 3rd class life science textbooks it is individual (f:167; $9.5 \%$ ) and group work (f:6; 3.5\%). When Figures 7 and 8 are separately investigated, both generally and at class level, it was documented that the activities included in life science textbooks directed students more towards individual work rather than group work.

\section{Sources required by students for activities included in life science textbooks}

In the context of the fourth subproblem in the research, attempts were made to determine the sources required by students for activities included in life science textbooks. These sources are given in Figure 9.

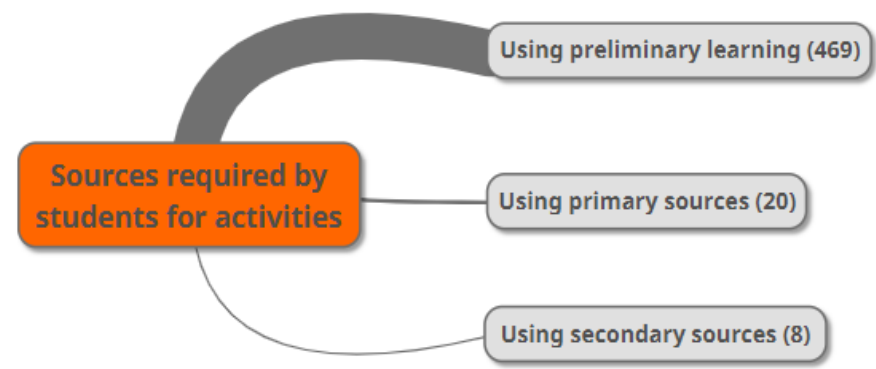

Figure 9. Sources required by students for activities included in life science textbooks. 
When Figure 9 is investigated, attempts were made to determine students' sources during activities included in life science textbooks. These sources were coded as using preliminary learning (f:469; $94.4 \%$ ), using primary sources (f:20; $4.0 \%$ ) and using secondary sources (f:8; 1.6\%). Examples of using preliminary learning include 'Why is Yasemin excited?' (LSTB1, p.13), 'What do you pay attention to when going to school and coming home from school?' (LSTB, p.18), 'Give examples of statements of kindness. Say what situations you would use these statements in.' (LSTB2, p.36), 'The following table gives the Mutlu family's spending for one month. Write your answers in accordance with the table.' (LSTB2, p.73), 'Briefly write the professions you see around you and the characteristics of people working in these professions.' (LSTB3, p.48) and 'Look at the following pictures. Read the speech balloons. What problem had Tuna encountered? Explain. What should Tuna do to avoid this kind of problem? Write your answer.' (LSTB3, p.93). Examples of the code related to using primary sources include 'Let's explore the school with your teacher. What sections of the school are to the right, left, above and below your classroom? Let's learn and say these.' (LSTB1, p.22), 'Have you watched your mother or father when they are cooking? What do they pay attention to when cooking?' (LSTB1, p.102), 'What are the contributions to the family budget of using resources economically? Learn by asking older members of your family. Write the information you learn at the points below' (LSTB2, p.74),'Color the section of the world in daytime in red and the section of the world in darkness in blue in the following picture.' (LSTB2, p.219) and 'Give examples of assistance and solidarity activities in your school.' (LSTB3, p.33). For the code related to using secondary sources, examples include 'Let's research Atatürk's childhood. Share your information with your friends.' (LSTB1, p.155), 'Let's learn the names of plants found where you live. Let's get help from our elders while doing this. Write the required information below' (LSTB1, p.176), 'Research the reasons for the great diversity in production activities in our country. Write the information you learn in the space below' (LSTB2, p.178), 'Write the information and features of the historical items below the pictures. You can use colored felt-tip markers when you write' (LSTB3, p.159) and 'You will research what the duties and responsibilities of our elders are to develop our country' (LSTB3, p. 163), etc. According to class level, the distribution of sources required by activities included in life science textbooks is given in Figure 10.

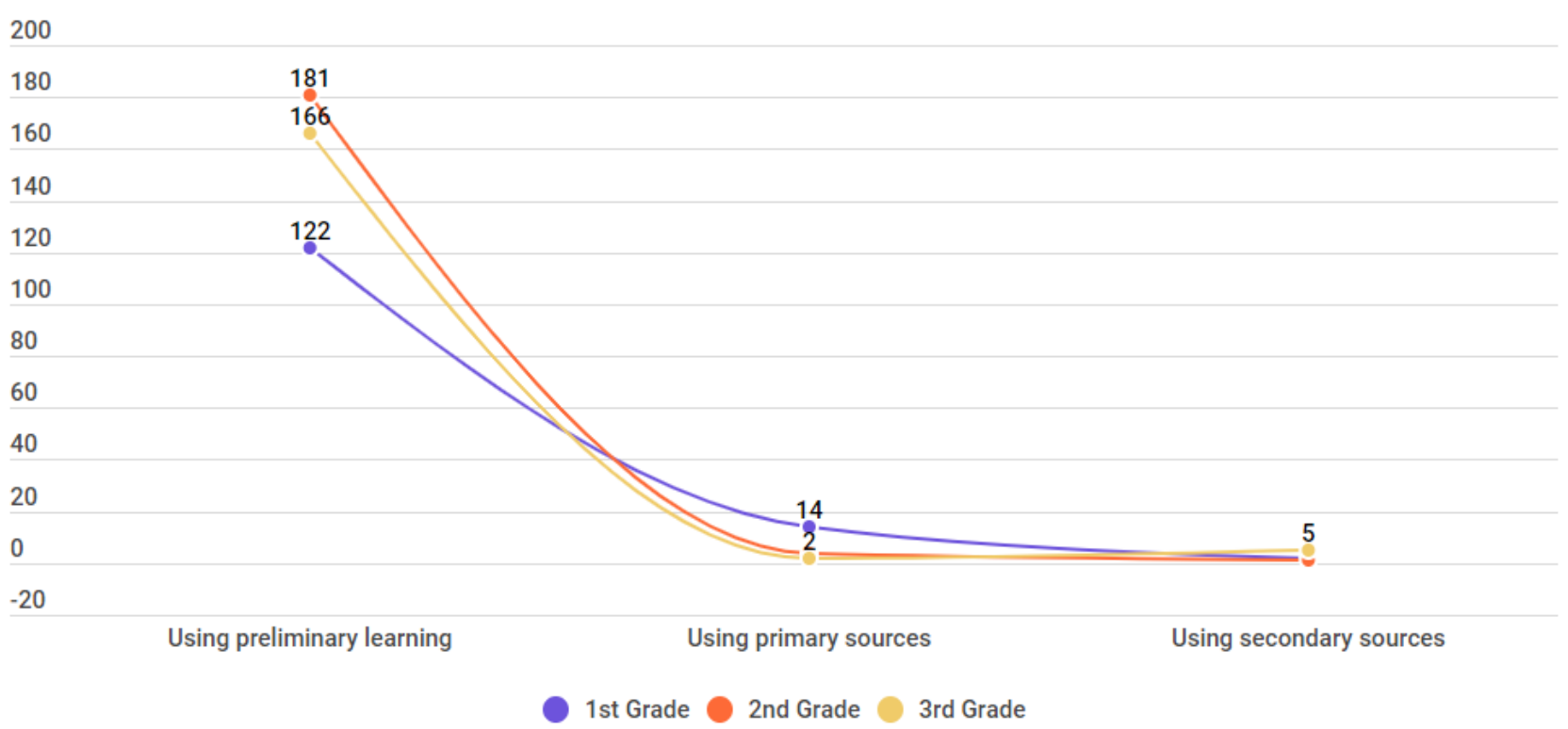

Figure 10. Distribution of sources required by students for activities included in life science textbooks according to class level.

Figure 10 shows the distribution of sources required by activities included in life science textbooks according to class level. Accordingly, activities included in the 1st class life science textbook required prior learning (f:122; 88.4\%), use of primary sources (f:14; 10.1\%), and use of secondary sources (f:2; $1.4 \%$ ). For 2nd class life science textbooks, activities required preliminary learning (f:181; $97.3 \%$ ), use of primary sources (f:4; $2.2 \%$ ) and use of secondary sources (f:1; $0.5 \%$ ). In 3rd class life science textbooks, activities required prior 
learning (f:166; 95.6\%), use of primary sources (f:2; 1.2\%), and use of secondary sources (f:5; $2.9 \%)$. In this situation, life science textbooks do not direct students toward different sources but mainly direct students to act based on prior learning.

\section{Discussion and Conclusion}

This research aimed to reveal a broad description of activities included in primary school life science textbooks. The activities included in the study's textbooks were investigated in terms of thinking skills targeted for development, aim, learning experience for the task, work form, and sources required for the activity. Each dimension investigated in the activities provides essential feedback about the quality of experiences that occupy students.

The first dimension investigated in textbooks within the research scope was the thinking skills targeted for development. As is known, especially from 2005 to the present, the aim in Turkey has been to develop an integrated understanding of thinking skills and lesson content in the curriculum. In this way, the aim is to include the target of developing thinking skills within class implementations. Resnick (1987) stated this approach creates a natural knowledge base and environment where higher-order skills can be applied and developed. When the aims and rationale of the current curriculum are investigated, the importance of higherorder thinking skills is underlined; it appears Turkey included these in the competence framework and areaspecific skills. This scope seems the life science curriculum includes 23 thinking skills (MEB, 2018). When the approach adopted in the curriculum is noted, it is expected that activities included in textbooks will have the aim of developing thinking skills stated in the program within a particular system. When the distribution showing the basis of thinking skills targeted for development in activities included in life science textbooks is investigated, it appears 16 different thinking skills were targeted for development. Of this number, 15 were included in 1st and 2nd class books, with 16 included in 3rd class books. It appears the mean rate of activities targeting the development of higher-order thinking skills in the textbooks is $28.2 \%$. This leads to the need to increase the quality of activities aiming to develop higher-order thinking skills. In studies about gaining skills, Kaya, Artvinli, and Önal (2007) stated that most activities just asked for responses to questions. A different investigation of social science textbooks mentioned similar findings (Gezer \& İlhan, 2015).

When the thinking skills targeted for development in activities included in life science textbooks are examined closely, in 1st, 2nd, and 3rd class textbooks, there appears to be a low rate of higher-order thinking skills directly related to the aim and vision of the life science curriculum like problem-solving $(0.7 \%, 2.6 \%$, $6.9 \%)$, creative thinking $(2.1 \%, 4.8 \%, 2.9 \%)$, making inferences $(1.1 \%, 1.4 \%, 5.2 \%)$ and assessment $(2.1 \%, 0$, $2.9 \%$ ). Additionally, none of the textbooks were found to have any activity targeting the development of interrogative thinking skills. This rate in the investigated activities indicates severe deficiencies in the textbooks about developing higher-order thinking skills. Similarly, according to research examining teacher opinions about the outcome status for basic skills in the life science curriculum, it was determined that creative thinking was one of the skills considered to be gained least by students (Öztürk, 2015). Teachers' belief that these skills are acquired least leads to the consideration that textbooks are practical about this competency. Research about the primary distribution of thinking skills outcomes included in social science field curricula showed low rates for results targeting the development of questioning, problem-solving, assessment, and innovative thinking skills (Bayrak Özmutlu, 2020). When this study and the current research findings are evaluated together, the curriculum's sufficiency for thinking skills development appears to be parallel with textbooks' adequacy.

The research shows that more than half of activities included in life science textbooks at all three class levels belong to the explanation, recall, and differentiation thinking skills. Based on this result, it is possible to interpret that textbooks' activities do not reflect the variety of the 23 skills included in the curriculum. It is possible to see similar findings in recent research about the social science lesson curriculum. A study 
investigating the life science curriculum outcome (Bayrak Özmutlu, 2020) stated that thinking skills did not have homogeneous distribution. The results did not reflect the thinking skills included in the explanation section of the curriculum. Another study by Çoban and Akşit (2018) stated that since 2005 curriculum development studies had been performed; however, rooted changes had not been completed in the current curriculum's content dimension. Bektaş, Sellum, and Polat (2019) stated that the 2018 life science curriculum was insufficient for critical and creative thinking skills. The area-specific abilities included in the 2018 curriculum of critical reading, innovative, and problem-solving thinking skills were observed in a deficient proportion of activities targeting the development of questioning, creative thinking, and problem-solving thinking skills. Contrary to these studies, though research by Doğan (2014) stated that the critical thinking skill was most common in 1st-3rd class life science textbooks, as underlined by Taş and Kıroğlu (2018) and Bayrak Özmutlu (2020), it is necessary to emphasize that there is a need for activities in textbooks to create relationships between outcomes and thinking skills.

Another result indicated by the study findings is that the thinking skills targeted for development activities in textbooks did not have proportional distribution between themselves or based on stages. For example, 55 activities targeted thinking skills development in the 2nd class life science textbook, with five activities targeting problem-solving cognitive skills. Research with similar results concluded that in social science workbooks, common and lesson-specific skills did not have balanced distribution at all class levels, and skills did not display a balanced and elevating graph from lower classes to higher classes (Aydemir \& Adamaz, 2017). TheThe skills included in the curriculum should support each other, and no skill is more important than another. As a result, balanced distributions of skills should be ensured (Aydemir \& Adamaz, 2017; Semerci \& Yanpar-Yelken, 2010; Taşkıran, 2014). This disproportional distribution of activities included in textbooks in terms of thinking skills leads to consideration about the rate of attention paid to the development of thinking skills in the textbooks' design process.

The second dimension investigated for activities included in textbooks was their aim. The target was to examine the rate of activities that repeated what was learned and those targeting deeper learning by investigating this dimension. Activities ensuring the possibility of applying what is learned and deeper learning in textbooks have great importance for the permanence of learning and transfer to higher-order learning. For textbooks to exceed the aims of just repetition and practice and be resources guiding students in transferring learning to higher levels, it has tremendous importance that activities are developed by paying attention to these requirements. When activities included in life science textbooks are investigated in terms of aims, it appears the highest proportion were activities repeating learning. This was followed by preparation to learn, deepening learning, and applying learning in this order. Activities involving deepening and learning in life science textbooks showed a parallel increase to class levels, with a fall in preparing for learning and repeating learning activities with increased class level. It appears the proportion of activities to deepen learning has a low rate of $1 / 5$ among all activities. Here, it is essential to state that all activities to prepare for learning in textbooks were in the form of simple question sentences. A similar situation was mentioned in research investigating social science textbooks. Gezer and İlhan (2015) recommended reducing questions with a single direction structure in social science textbooks and including more questions representing other levels in their study.

The third dimension investigated in textbooks is the learning experience the activity directed students towards. This investigation aimed to see the compatibility between the teaching and learning approach adopted by the curriculum in activities included in textbooks with the nature and aims of life science lessons. When activities included in life science textbooks are investigated in learning experiences, more than half of activities were repeat-based work and studies directing personal experiences. Here, it is essential to state that all activities directing students to think about personal experiences were based on a single question to express 
their thoughts about a topic, with no structured activities. Additionally, activities directing toward innovative products and solutions to real-life problems had the lowest rate among activities included in life science textbooks. The interdisciplinary understanding of the life science curriculum offers students the opportunity to gain essential life skills, develop positive personal qualities, real-life learning-teaching processes, and school learning (Güldalı \& Demirbaş, 2018). It appears the investigated textbooks are distant from supporting students in being creative and problem-solving individuals.

When the learning experience students are directed towards during activities included in life science textbooks is investigated, the rate of activities about real-life situations was $9.5 \%$. In comparison, the rate of activities about real-life problem solving was $2.6 \%$. This situation shows textbooks are weak in terms of forming relationships with daily life. Studies (Güven, 2010; Öztürk \& Öğreten, 2017; Yıldırım, 2006) indicated a similar problem in life science textbooks. Life science is a lesson aiming to ease the child's adjustment to society and life and is nested in real life. As a result, in addition to this lesson providing students with essential life skills, it is to gain skills to help cope with adverse situations encountered in daily life (Gündoğan, 2017). It is considered very important to include work developing problem-solving skills in the design process for textbook activities. Again, research by Bayrak- Özmutlu (2020) stated that there was no outcome aiming to develop problem-solving skills in the life science curriculum. At this point, it may be interpreted as showing that the textbooks reflect the deficiencies observed in the curriculum. It is possible to predict that the textbook's quality cannot exceed the quality of the curriculum.

The fourth dimension of textbooks investigated was the form of work in the activities. Within this scope, the aim was to see the rate at which activities supported cooperative work. Analysis based on the form of work showed that nearly all activities involved individual work. Within all books, the rate of activities with group work was below $2 \%$. This situation is very thought-provoking about why cooperative work, with great importance for values, teaching. Besides, the efficacy of gaining higher-order thinking skills during educational activities was not reflected in textbooks. Research investigating the core values included in social studies textbooks recommends the need for more inclusion of the solidarity value related to cooperative research in textbooks (Tabak \& Yaylak, 2020). Teachers design teaching processes to reveal the thinking skills of students in lessons. Research on this topic concluded that most class and social studies (İlter, 2018; Yaylak, 2020) teachers provide half or more than half of social studies lesson outcomes through passive learning methods (teacher-centered teaching design); as a result, they adopt a more traditional teaching approach during teaching processes. The teacher-centered teaching approach is given weight in teaching processes, and teachers tend to avoid student-centered teaching approaches, especially. (Covill, 2011; Faruji, 2012; Oh \& Kim, 2013). On the other hand, Bektaş, Sellum, and Polat (2019), in research investigating the 2018 life science curriculum, stated that it included sufficient skills statements about cooperation, contrary to this research's results. Considering that teachers use textbooks as the primary teaching material in work performed in class, care needs to be taken from many aspects like agreement on effectiveness for learning in the design of activities included in textbooks and compatibility with teaching approaches adopted in the curriculum.

The final dimension investigated in textbooks is the sources needed during the activities. This investigation revealed the rate at which students had to research, study or access information sources during activities in the textbooks. Nearly all activities included in the textbooks investigated in this research could be completed by students' prior learning and information available in the textbooks. In fact, in the learning process, encouraging students to access primary/secondary sources is critical for learning. From this aspect, textbooks transform into a closed-circuit teaching application. A practical textbook is expected to encourage students to find up-to-date, reliable information sources, enjoy research, and question their access. The investigated books appear to be distant in this aspect from directing students toward group work and interaction with information sources. 
The appearance of activities in terms of the form of work and sources required during activities leads to consideration of the rate of attention paid to active learning, cooperative-based learning requirements, and the life science lesson's nature during the textbook design process. It is expected that textbooks will be essential guides to gain skills working in groups and access information sources for students' life science lessons. Research investigating the life science curriculum outcomes in terms of social skills (Gündoğan, 2017) showed that $1 / 3$ of the results were related to social skills. However, the life science construct and vision have an entirely student-centered understanding (Tay \& Baş, 2015). In this context, statements like 'having basic life skills,' 'knowing themselves,' 'researching," 'high self-confidence,' and 'reconciled to themselves and their environment' directly emphasize the importance of social skills. As a result, attention is drawn to the extent of social skills in the life science curriculum's vision.

It appears similar findings are mentioned in the relevant literature. For example, Güven (2010) found that nearly $1 / 4$ of teachers stated that life science textbooks were insufficient for students playing an active role in class. In Kabapinar and Akbal's (2010) research, teachers said children could not configure information through textbooks. Students playing an active role in class configure what they learn in the own mind by participating in active learning processes and reproduce the data. Students interact with each other during active learning, share problems, and information, and research, think, and discover to complete learning (Açıkgöz, 2002). From this perspective, textbooks with the property of ensuring students play an active role in class will bring their learning to advanced-level thinking skills. In the research, the textbooks were very weak about the two essential parameters for active learning of direction towards group activities and accessing information sources. $2.1 \%$ of activities in textbooks directed students toward group work, and $5.9 \%$ directed students towards primary or secondary sources. These rates display for all to see the need to review the activities included in textbooks with an understanding based on current learning concepts. There is a benefit in revising life science textbooks' content to enrich them in making it easier for students to play an active role in learning. Activities that make it easier for students to learn themselves in workbooks (researchinvestigation, matching, sentence completion, crosswords, puzzles, etc.) should be included at much higher rates (Güven, 2010).

The 16 different thinking skills targeted for development in life science textbooks are encountered as a positive aspect. However, the lack of proportional distribution of thinking skills within themselves and on a staged basis, the low inclusion rate for a range of thinking skills while giving excess weight to certain skills, and the lack of direction toward group work and accessing information sources indicate points that need to be developed in the textbooks. For schools to fulfill the future world's requirements, it is necessary for textbooks to use teaching and learning concepts and approaches proven to be effective for learning outcomes in educational science and with the potential to develop thinking skills in the subject area. From this aspect, designing activities focuses on how opportunities in the life science lesson benefit correctly in terms of learning requirements and thinking skills targeted for development in activities carries great importance. Within this scope, it is essential during the development process for textbooks to focus on topics like what the learning requirements are which serve permanence of learning and bring learning outcomes to more advanced levels; how do activities meet these requirements; how should activities be designed to develop higher-order thinking skills; and what steps must be followed for activities to fulfill all provisions of the curriculum.

- The number of activities to develop higher-order thinking skills should be increased in textbooks.

- The number of activities about deepening learning should be increased in textbooks.

- Activities about preparation and accessing information sources in textbooks should not be in the form of singular questions. Activities prepared in this scope require better configuration.

- The number of activities permitting students to work in groups should be increased in textbooks. 
Form of work should be added to textbook assessment criteria.

- The number of activities directing students to access primary and secondary information sources should be increased in textbooks. In these activities, the information should be included about how to access these sources and interrogate the validity and reliability of information accessed.

- Textbooks should include information about the aim, scope, thinking skill developed, concept, and principle for each activity.

- Before implementing any textbook, pilot applications should be completed with students.

- Activities included in life science textbooks should be written by observing the development process and class level of students and curriculum principles (from simple to complex, from easy to challenging, etc.). 


\section{REFERENCES}

Açıkgöz, K. Ü. (2002). Aktiföğrenme. İzmir: Eğitim Dünyası Yayınları.

Akınoğlu, O. (2003). Hayat bilgisi öğretimi. In C. Öztürk, \& D. Dilek (Ed.) Hayat bilgisi ve sosyal bilgiler öğretimi (p.1-13). Ankara: Pagem Akademi.

Anderson, L. W., \& Krathwohl, D. R. (2001). A Taxonomy for learning, teaching, and assessing. A revision of bloom's taxonomy of educational objectives. Longman: New York.

Avcl, E. K., \& Faiz, M. (2018). Investigation of the skills and values in the "Effective Citizenship" theme in 4th and 5th-grade social studies textbooks. International Journal of New Approaches in Social Studies (IJONASS), 2(1), 1-21. https://dergipark.org.tr/tr/download/article-file/503075

Aydemir, M., \& Adamaz, K. (2017). Examination of student workbooks on social studies in terms of student skills achieved by social studies curriculum. International Journal of Field Education, 3(1), 106-119. https://dergipark.org.tr/tr/download/article-file/334551

Bayrak-Özmutlu, E. (2020). Outcomes social studies curriculum based on thinking skills. Turkish Studies Education, 15(1), 15-32. Doi: 10.29228/TurkishStudies.40359.

Baysal, Z. N., Çarıkçı, S., \& Yaşar, E. B. (2016). Classroom teachers' awareness of teaching thinking skills. Journal of Qualitative Research in Education, 5(1), 7-28. Doi: 10.14689/issn.2148-2624.1.5c1s1m

Bektaş, M., Sellum, F, S. \& Polat, D. (2019). An examination of the 2018 life study lesson Curriculum in terms of 21st-century learning and innovation skills. Sakarya University Journal of Education, 9(1), 129147. Doi: $10.19126 /$ suje. 537104

Beyer, B. (1984). Improving thinking skills: Practical approaches. The Phi Delta Kappan, 65(8), 556-560. https://www.jstor.org/stable/20387119?seq=1

Binkley, M., Erstad, O., Herman, J., Raizen, S., Ripley, M., Miller-Ricci, M., \& Rumble, M. (2012). In Assessment and Teaching of 21st Century Skills. Dordrecht: Springer.

Bloom, B. S. (Ed.) (1956). Taxonomy of educational objectives. The classification of educational goals. Handbook I: Cognitive domain. New York: Longmans, Gren And Company Inc.

Candan, D. G., \& Ergen, G. (2014). Analysis of the 3rd class life science textbooks about that including fundamental universal values. Uşak University Journal of Social Sciences, 7(1), 134-161. https://dergipark.org.tr/tr/download/article-file/202223

Creswell, J. W., \& Miller, D. L. (2000). Determining validity in qualitative inquiry. Theory into Practice, 39, 124-130. Doi: 10.1207/s15430421tip3903_2

Çoban, O., \& Akşit, İ. (2018). Comparison of 2005 and 2017 social studies curriculum in terms of learning area, acquisition, concept, value, and skill. Journal of History Culture and Art Research, 7(1), 479-505. Doi: 10.7596/taksad.v7i1.1395

Covill, A. E. (2011). College students perceptions of the traditional lecture method. College Student Journal, 45(1), 2-15. https://eric.ed.gov/?id=EJ996351

Creswell, J. W. (2014). Research design. (G. Haciömeroğlu, Çev.). Demir, Ş. B. (Ed.). Ankara: Eğiten Kitap.

Demirkaya, H. (2017). Sosyal bilgiler öğretiminde ders kitabı. In R. Sever, \& E. Koçoğlu Sosyal bilgiler öğretiminde eğitim teknolojileri ve materyal tasarımı. (87-101). Ankara: Pegem Akademi.

Doğan, H. (2014). The standard basic skills' level of existence took part in the primary school curriculum in workbook activities. (Thesis no: 372296). [Unpublished master's thesis, Marmara University, Institute of 
Education Sciences, İstanbul].

EARGED, MEB (2008). Sınıf öğretmenlerinin hizmet içi eğitim ihtiyaçlarının belirlenmesi. Ankara: MEB Yayınları.

Erol, B., \& Kiroğlu, K. (2012). The evaluation of 'Science of Life' textbooks in terms of language and expression. Selçuk University Journal of Turkic Studies, 32, 155-176. http://sutad.selcuk.edu.tr/sutad/article/view/570/558

Ertürk, M., \& Güler, E. (2017). 5. 6. ve 7. sınıf sosyal bilgiler ders kitaplarının öğretmen görüşlerine göre incelenmesi (Muğla ili örneği). Uluslararası Türk Ĕ̆itim Bilimleri Dergisi,2017(8), 64-76. https://dergipark.org.tr/tr/download/article-file/408561

Faruji, L. F. (2012). Teachers' teaching styles at the English Language institute in Iran. International Journal of Social Sciences and Education, 2(1), 364-373.

Gelen, İ. (2017). P21- 21st-century skill frameworks in curriculum and instruction (USA Practices). Journal of Interdisciplinary Educational Research, 1(2), 15-29. https://dergipark.org.tr/tr/download/articlefile/386403

Gagne, R. M., \& Briggs, L. J. (1979). Principles of instructional design (2nd Ed.). New York: Holt, Rinehart, And Winston.

Gözütok, F. D., Taş, İ. D., Rüzgar, M. E., Akçatepe, A. G., \& Yetkiner, A. (2015). Evaluation of primary school first-grade life studies books. Elementary Education Online, 14(3), 825-844. Doi: 10.17051/io.2015.45371

Gülüm, K., \& Çeltik, D. (2014). Investigation and recommendations to improve the quality of workbook and textbook of life science education on the 2'nd class of the primary school. Cumhuriyet University Faculty of Literature Journal of Social Sciences, 38(1), 46-58. https://dergipark.org.tr/en/download/article-file/49930

Güler, A., Halıcıoğlu, M., \& Taşğın, S. (2013). Sosyal bilimlerde nitel araştırma yöntemleri. Ankara: Seçkin Yayıncilık.

Gündoğan, A. (2017). The reflection of the attitudes and learning processes to learning environments with authentic tasks in life science class. (Thesis no: 458657). [Unpublished doctoral dissertation, Anadolu University, Institute of Educational Sciences, Eskişehir].

Gürdoğan-Bayır, Ö. (2015). Examining the improvement of conflict resolution skills in the elementary fourth grade Social Studies course. (Thesis no: 395189). [Unpublished doctoral dissertation, Anadolu University, Institute of Educational Sciences, Eskişehir].

Güven, S., \& Püsküllü, M. A. (2017). The content analysis of the studies about life science textbooks. The Journal of International Lingual Social and Educational Sciences, 3(2), 75-86. https://dergipark.org.tr/tr/download/article-file/383959

Güven, S. (2010). The evaluation of primary education life sciences coursebooks and workbooks according to the teachers' views. Education and Science, 35(156), 84-95. http://egitimvebilim.ted.org.tr/index.php/EB/article/view/97/233

Haladyna, T. M. (1997). Writing test items to evaluate higher-order thinking. Boston: Allyn And Bacon.

Harari, Y. N. (2018). 21.yüzyıl için 21 ders. Şiral, S. (Çev.), İstanbul: Kolektif Kitap.

Hayırsever, F., \& Kisakürek, M. A. (2014). Evaluation of social studies textbook in terms of the aimed skills 
to be acquired by students according to the primary school curriculum. International Journal of $\begin{array}{lllll}\text { Curriculum and Instructional Studies } & \text { (IJOCIS), } & 4(8), & \text { 23-42. }\end{array}$ http://ijocis.com/index.php/ijocis/article/view/19/17

İlter, İ. (2018). A review of teachers' teaching methods and practices about social studies instruction. Journal of Theoretical Educational Science, 11(1), 1-29. Doi: 10.30831/akukeg.338520

Johnson, S., \& Siegel, H. (2010). Teaching thinking: Key debates in educational policy. In C. Winch (Ed.), On thinking skills (113-125). London: Uk Continuum Press.

Johnson, B., \& Christensen, L. (2014). Educational research quantitative, qualitative and mixed approaches: Mixed methods (A. Türkdoğan, Çev.). Ankara: Eğiten Kitap.

Kabapınar, Y. (2014). Kuramdan uygulamaya sosyal bilgiler öğretimi. Ankara: Pegem Akademi.

Kabapinar, Y. (2007). The presentation of social issues and values in the primary social studies textbooks written in the 1998 and 2004 curricula: Have we moved to a different stage regarding function and quality? Marmara University Atatürk Faculty of Education Journal of Educational Sciences, 25(25), 109127. https://dergipark.org.tr/tr/download/article-file/1645

Kabapinar, Y., \& Akbal, Y. (2010). Classroom teachers' viewpoints on "Life Studies" textbooks written in the line of 1998 and 2004 primary programs. Marmara University Atatürk Faculty of Education Journal of Educational Sciences, 32(32), 95-122. https://dergipark.org.tr/tr/download/article-file/1683

Karabağ, G. (2009). Hayat bilgisi dersinin tarihçesi. In B. Tay (Ed.) Hayat bilgisi öğretimi. Ankara: Maya Akademi.

Kaya, N., Artvinli, E., \& Önal, H. (2007, 15-17 Kasım). Sosyal bilgiler programına göre öğrenci çalışma kitaplarının beceri ve değerleri gerçekleştirebilme düzeyi. I. Ulusal İlköğretim Kongresi'nde sunulmuştur. Ankara.

Kutlu, Ö., Doğan, C. D., \& Karakaya, İ. (2010). Öğrenci başarısının değerlendirilmesi. performansa ve portfolyoya dayalı durum belirleme. Ankara: Pegem Akademi.

Larson, L. C., \& Miller, T. N. (2011). 21st-century skills: prepare students for the future. Kappa Delta Pi Record, 47(3), 121-123. Doi: 10.1080/00228958.2011.10516575

Marzano, R. J. (2001). Designing a new taxonomy of educational objectives. Thousand Oak, California: Corwin Press, Inc.

Mesleki Yeterlilikler Kurumu (2015). Türkiye yeterlilikler çerçevesi. Resmi Gazete 29581.

Miles, B. M., \& Huberman, A. M. (1994). Qualitative data analysis. London: International Educational and Professional Publisher.

Millî Eğitim Bakanlığı [MEB]. (2018). Sosyal bilgiler dersi öğretim programı (4-8 sımıflar). Ankara: Millî Eğitim Bakanlığı Yayınları.

Orhan Göksün, D., \& Kurt, A. A. (2017). The relationship between pre-service teachers' use of 21st-century learner skills and 21st-century teacher skills. Education and Science, 42(190). Doi: 10.15390/EB.2017.7089

Oh, P. S., \& Kim, K. S. (2013). Pedagogical transformations of science content knowledge in Korean elementary classrooms. International Journal of Science Education, 35(9), 1590-1624. Doi: 10.1080/09500693.2012.719246

Öztürk, T. (2015). Teacher opinions on gaining of basic skills in the life studies curriculum by students. 
Education and Science, 40(181), 271-292. Doi: 10.15390/EB.2015.4363

Öztürk, T., \& Özkan, Z. S. (2018). Investigation of texts and images in life science textbooks in terms of values. Journal of Qualitative Research in Education, 6(1), 172-204. Doi: 10.14689/issn.21482624.1.6c1s8m

Öztürk, T., \& Öğreten, A. (2017). Teachers' opinions about the sufficiency of social studies textbooks to gain the 2005 year's social studies curriculum skills. Anadolu Journal of Educational Sciences International, 7(2), 234-259. Doi: 10.18039/ajesi.333727

Patton, M. Q. (2014). Nitel araştırma ve değerlendirme yöntemleri. Ankara: Pegem Akademi.

Resnick, L. B. (1987). The thinking curriculum. Washington, DC: National Academy Press.

Resnick, L. B. (2010). Nested learning systems for the thinking curriculum. Educational Researcher. 39(3), 183197. Doi: 10.3102/0013189X10364671

Romiszowski, A. J. (1981). A new look at instructional design. Part I. learning: Restructuring one's concepts. British Journal of Educational Technology, 12(1), 19-48.

Saldana, J. (2013). The coding of manual for qualitative researchers. Sage Publications.

Sarıtaş, E., \& Şahin, Ü. (2019). An examination of gender roles in social sciences course books. Mehmet Akif Ersoy University Journal of Education Faculty, 48, 463-477. https://dergipark.org.tr/tr/download/articlefile/555268

Scott, J., \& Marshall, G. (2015). A dictionary of sociology (3 revs. ed.). London: Oxford University Press.

Semerci, N., \& Yanpar Yelken, T. (2010). Teacher views regarding common basic skills in primary school curricula (Example of Elazığ Provınce). Firat University Journal of Eastern Studies, 8(2), 47-54.

Senemoğlu, N. (2011). College of education students' approaches to learning and study skills. Education and Science, 36(160), 65-80. http://egitimvebilim.ted.org.tr/index.php/EB/article/view/335/260

Tabak, S., \& Yaylak, E. (2020). The place of root values in social studies textbook. International Journal of Eurasian Education and Culture, 8, 1-51. Doi: 10.35826/ijoecc.58

Taş, H., \& Kıroğlu, K. (2018). Assessment of the 2017 primary school social studies curriculum according to teachers' views. Elementary Education Online, 17(2), 697-716. Doi: 10.17051/ilkonline.2018.419041

Taşkıran, C. (2014). To investigate in terms of the thinking skills to gains of sixth-grade social studies curriculum. International Turkish Journal of Educational Sciences, 2, 1-13. https://dergipark.org.tr/en/pub/goputeb/issue/7322/95815

Tay, B., \& Baş, M. (2016). 2009 ve 2015 yılı hayat bilgisi dersi öğretim programlarının karşılaştırılması. Bayburt Eğitim Fakültesi 341-374. https://dergipark.org.tr/tr/download/article-file/159876

Uçuş Güldalı, Ş., \& Demirbaş, İ. (2017). Examination of the spirality of the preschool curriculum and 1stgrade social studies curriculum. Mersin University Journal of the Faculty of Education, 13(3), 1084-1105. Doi: $10.17860 /$ mersinefd.322800

Ütkür, N. (2018) An examination of the articles on life studies and social studies textbooks between 20052018. Gazi Journal of Education Sciences, 4(3), 1-11. Doi: 10.30855/gjes.2018.04.03.001

Yaylak, E. (2020). Evaluation of teaching methods and practices of social studies teachers. Ahi Evran University Journal of Social Sciences Institute, 6(1), 187-205. Doi: 10.31592/aeusbed.621664 
Yıldırım, A. (2006). Teachers' opinions about the new primary school program concerning to natural studies coursebook (Case of Elazı̆̆ city). (Thesis no:187119). [Unpublished Master's Thesis, Firat University, Institute of Educational Sciences, Elazig].

Zayimoğlu-Öztürk, F. (2020). Thinking skills and their place in children's universities. In M. Kilinç, \& İ. Kösterelioğlu. Children's University in Turkey. Ankara: Pegem Akademi. 